\title{
Association between anterior open bite and pacifier sucking habit in schoolchildren in a city of southern Brazil
}

\author{
Claudiane Tibolla', Lilian Rigo² ${ }^{2}$ Lincoln Issamu Nojima ${ }^{3}$, Anamaria Estacia ${ }^{4}$ Eduardo Gianoni Frizzo', Leodinei Lodi ${ }^{5}$
}

Objective: The objective of this study was to verify from a school-based epidemiological survey, the prevalence of anterior open bite, analyzing the influence of pacifier habit in the school. Methods: The first step was a questionnaire for the parents, and later clinical examinations in 237 school children, 3-14 years old, in the city of Santo Expedito do Sul/RS, Brazil. Results: The population gender distribution was $50.3 \%$ boys and $49.4 \%$ girls with a mean age of 8.63 years, and $16 \%$ had primary dentition, $50.2 \%$ mixed dentition and $33.8 \%$ permanent dentition. There was a $22.8 \%$ prevalence of anterior open bite, obtaining a significant association between anterior open bite and the pacifier sucking habit on the three dentitions. Conclusion: The duration and frequency of the habit were strongly associated with anterior open bite malocclusion in the deciduous and mixed dentitions.

Keywords: Malocclusion. Prevalence. Open bite.

Objetivo: o objetivo deste estudo foi verificar, a partir de um levantamento epidemiológico de base escolar, a prevalência de mordida aberta anterior, analisando a influência do hábito da chupeta no seu estabelecimento. Métodos: na primeira etapa, foi aplicado um questionário aos responsáveis e, posteriormente, foram feitos exames clínicos em 237 escolares de 3 a 14 anos do município Santo Expedito do Sul/RS. Resultados: o tamanho da população, segundo o sexo, foi de 50,3\% meninos e 49,4\% meninas, com média de idade de 8,6 anos, sendo que $16 \%$ possuíam dentição decídua; $50,2 \%$, dentição mista; e $33,8 \%$, dentição permanente. Verificou-se uma prevalência de 22,8\% de mordida aberta anterior, obtendo-se associação significativa entre a mordida aberta anterior e o hábito de sucção de chupeta, nas três dentições. Conclusão: a duração e a frequência do hábito estiveram fortemente associadas à má oclusão de mordida aberta anterior nas dentições decídua e mista.

Palavras-chave: Má oclusão. Prevalência. Mordida aberta.

${ }^{1}$ Specialist in Orthodontics, Advanced Unit Uningá-Passo Fundo

${ }^{2}$ Head, School of Dentistry, IMED, Passo Fundo, RS

${ }^{3}$ Associate Professor of Orthodontics, Federal University of Rio de Janeiro. Visiting Associate Professor, Case Western Reserve University.

${ }^{4}$ Coordinator, Specialization Course in Orthodontics, Post graduation Unit at UningáPasso Fundo

${ }^{5}$ Professor, School of Dentistry, URI/Erechim
How to cite this article: Tibolla C, Rigo L, Nojima LI, Estacia A, Frizzo EG, Lodi L. Association between anterior open bite and pacifier sucking habit in schoolchildren in a city of southern Brazil. Dental Press J Orthod. 2012 Nov-Dec;17(6):89-96.

Submitted: June 8, 2009 - Revised and accepted: April 12, 2010

» The author reports no commercial, proprietary or financial interest in the products or companies described in this article.

Contact address: Lilian Rigo

Av. Major João Schell, 1121 - CEP: 99.020-020 - Passo Fundo/RS - Brazil

E-mail: lilianrigo@via-rs.net 


\section{INTRODUCTION}

Malocclusions are morphological deviations of biophysical nature in the masticatory apparatus, it can be understood as the arrangement of teeth in the dental arch and their relation with the bone bases and related structures in a disharmonious way. ${ }^{1,2,3}$ Several authors have considered the normal pattern of occlusion almost an exception, so because of the high prevalence of malocclusion, it is considered an important public health problem. The study of malocclusion and its etiology is of fundamental importance to the dentist that, with early diagnosis and preventive measures, including awareness of the patient and guardians, can intercept difficult problems to solve in the long term. ${ }^{4}$

The anterior open bite is a common type of malocclusion, understood as a deficiency in the normal vertical contact between the opposite teeth, maybe occurring in a limited region or rarely throughout the dental arch. It consists of a discrepancy in the vertical direction, which makes it more difficult to be corrected and its final results seem to be less stable. ${ }^{5}$ People who have anterior open bite have no muscle balance, resulting in lack of relation between the jaws and interfering on facial harmony. The correct position of the tongue and lips and the normal performance of swallowing is essential for the maintenance of balance in the position of the teeth in the jaw and in the surrounding muscles. ${ }^{6}$

Harmful oral habits are understood as incorporated patterns of muscle contraction, of complex nature and unconscious character, it may act as deforming factors for growth and bone development, tooth position, in breathing and speech. ${ }^{7}$ According to authors, ${ }^{8}$ the effects of harmful habits on dentition depends on the frequency, intensity, duration, individual predisposition, age, and also the conditions of nutrition and health of the individual. In absence of one of the requirements time-intensity-frequency there will be no changes in the dental arches.

Therefore, the aim of this study is to determine the prevalence of open bite in children from 3-14 years of age in the city of São Expedito do Sul/RS, Brazil, as well as to verify the influence of duration and frequency of deleterious habits (pacifier use), in the establishment of this malocclusion. Since it is a new work in this location, the results of this research aims to support oral health programs for the population.

\section{METHODS}

\section{Study population}

This is a cross-sectional school-based research in two stages. First, we sent a self-administered questionnaire to parents and / or guardians. In a second step, a clinical examination was done in children and teenagers from local schools. The target population has 300 students, from 3 to 14 years of age, and 237 were actually assessed and were part of the analyzed sample. All students were enrolled in five public schools in rural and urban areas of Santo Expedito do Sul/RS, featuring a census. Data from IBGE $^{9}$ describe the population of Santo Expedito do Sul as having 2,683 residents in the city of all age groups. The small town is located in the northwest part of Rio Grande do Sul, Brazil.

The children were divided into three groups, according to dentition age:

» Deciduous: 3 to 5 years (16 females and 22 males), total of 38 children.

» Mixed dentition: 6 to 10 years (62 females and 57 males), total of 119 children.

» Permanent dentition: 11 to 14 years (39 females and 41 males), total of 80 teenagers.

Students who have already used or were using some type of orthodontic appliance, the students who had dental mutilations in the area above the arches, and those who did not have the Term of Consent signed by parent / guardian were not part of the survey.

The project was submitted and approved by the Ethics Committee in Research of the University of Maringá / Uningá, Resolution 196/96, determined by the National Research Council (CONEP), it was approved under protocol number 0082/08.

\section{Examiner calibration and data collection}

Prior to the pilot study, the calibration and measurement of the examiner, and the diagnostic criteria used for the measurement of anterior open bite, the distance between the incisal edges of maxillary central incisor and the incisal edges of lower incisors, using the CPI probe for this purpose were performed. ${ }^{10}$

As a research instrument a clinical examination on each child at the Unit of Primary Health Care in the city was carried out, using a properly sterilized millimeter probe for this procedure according to the biosafety standards. Another instrument used was a questionnaire given to the caregivers. 


\section{Pilot test}

The pilot test was conducted aiming to test the operation of the proposed method for the epidemiological survey, standardizing the fieldwork conduction, the use of evaluation and assessment instruments of the examiner, as well as the notes, ensuring the reliability of findings. This stage of the survey was to examine 20 children from a randomly chosen school.

\section{Analysis and interpretation of results}

The data was entered and stored in a specific database in SPSS version 15.0. In the first step of the analysis a descriptive statistics of studied variables was performed. Then, a bivariate analysis was performed using the chi-square test at a significance level of 5\% and confidence intervals of $95 \%$ to test the associations between the prevalence of open bite and other variables, followed by the estimation of odds ratio and confidence intervals.

\section{RESULTS}

\section{Descriptive analysis of the sample}

The sample size was similar regarding gender (nearly half in each group), and $16 \%$ had primary dentition, $50.2 \%$ mixed dentition and $33.8 \%$ permanent dentition. The mean age of the sample was 8.63 (SD 3.03) years. Most students lived in rural areas (92\%), and $85.2 \%$ were white. Demographic data are shown in Table 1.

\section{Inferential analysis of anterior open bite}

The overall prevalence in the three dentition of anterior open bite, the dependent variable of this research, was $22.8 \%$ (54), and $77.2 \%$ (183) did not show anterior open bite.

The prevalence of open bite in the deciduous dentition was $34.2 \%$ (13), $24.4 \%$ (29) in the mixed dentition, and permanent dentition obtained a prevalence of $15.0 \%$ (12).

The bivariate analysis evidenced a significant association between the variable anterior open bite and the habit of sucking a pacifier in the three dentitions $(\mathrm{p}<0.001)$. The students who had the habit of pacifier sucking and presented open bite malocclusion totaled a percentage of $36.5 \%$, with nearly 7.5 times more likely to have this malocclusion than those without the habit of sucking pacifiers (OR $=7.40$, 95\% CI 3.30 to 16.56) (Table 2).

When the dentitions were separately evaluated, there was also a statistical association in relation to the variable anterior open bite and sucking a pacifier ( $\mathrm{p}<0.000$ ). The students who had deciduous dentition and had the pacifier sucking habit in childhood had $65 \%$ of anterior open bite. In bivariate analysis, these children with deciduous teeth were nearly three times more likely to have open bite than those that did not have the pacifier habit $(\mathrm{OR}=2.85,95 \% \mathrm{CI} 1.57$ to 5.19). The students who had mixed dentition and had the pacifier sucking habit in childhood $37.3 \%$ had an-

Table 1 - Description of the sample from schools in the city of Santo Expedito do Sul-RS, $2008(n=237)$.

\begin{tabular}{|c|c|c|}
\hline DEMOGRAPHIC DATA & n (237) & $\%$ \\
\hline \multicolumn{3}{|l|}{ Dentition } \\
\hline Deciduous & 38 & 16.0 \\
\hline Mixed & 119 & 50.2 \\
\hline Permanent & 80 & 33.8 \\
\hline \multicolumn{3}{|l|}{ Gender } \\
\hline Male & 120 & 50.6 \\
\hline Female & 117 & 49.4 \\
\hline \multicolumn{3}{|l|}{ Ethnic group } \\
\hline White & 202 & 85.2 \\
\hline Brown & 23 & 9.7 \\
\hline Black & 12 & 5.1 \\
\hline \multicolumn{3}{|l|}{ Geographic location } \\
\hline Urban & 19 & 8.0 \\
\hline Rural & 218 & 92.0 \\
\hline
\end{tabular}


terior open bite, with almost 1.5 times more likely to have open bite than those who did not have the habit $(\mathrm{OR}=1.40,95 \% \mathrm{CI} 1.13$ to 1.75$)$. The children with permanent dentition and pacifier sucking habit had a $23.4 \%$ incidence of open bite, and almost 1.3 times more likely to have anterior open bite than those who did not have the sucking habit in childhood $(\mathrm{OR}=1.26$, 95\% CI 1.06 to 1.49) (Table 3).

There was a statistical relation regarding the variable anterior open bite and the duration in years of the pacifier sucking habit in deciduous and mixed dentitions $(\mathrm{p}<0.001)$. There was a percentage of $83.3 \%$ of children with open bite in the deciduous dentition and the presence of the habit for more than two years. In bivariate analysis, these children had 38 times more chance to have open bite than those who used a pacifier for less than 2 years (OR $=38.33$, 95\% CI 5.25265.98). $47.6 \%$ of students in the mixed dentition had anterior open bite, almost seven times more likely to have open bite than those who used a pacifier for less than 2 years $(\mathrm{OR}=6.86,95 \% \mathrm{CI} 2.73-17.26) .25 .9 \%$ of children with permanent dentition had anterior open bite, but without statistical association with duration of habit $(\mathrm{p}>0.05)$ (Table 4).

Table 2 - Relation between anterior open bite and pacifier sucking habits of the students of Santo Expedito do Sul-RS, 2008.

\begin{tabular}{|c|c|c|c|c|c|c|c|c|c|}
\hline \multirow{3}{*}{ Pacifier sucking } & \multicolumn{6}{|c|}{ Open bite } & \multirow{3}{*}{$\mathbf{p}$} & \multirow{3}{*}{ OR } & \multirow{3}{*}{$\mathrm{Cl} 95 \%$} \\
\hline & \multicolumn{2}{|c|}{ No } & \multicolumn{2}{|c|}{ Yes } & \multicolumn{2}{|c|}{ Total } & & & \\
\hline & $n$ & $\%$ & $n$ & $\%$ & $n$ & $\%$ & & & \\
\hline Absent & 103 & 92.8 & 8 & 7.2 & 111 & 100 & \multirow{3}{*}{${ }^{\star}<0.001$} & \multirow{3}{*}{7.403} & \multirow{3}{*}{$3.308-16.569$} \\
\hline Present & 80 & 63.5 & 46 & 36.5 & 126 & 100 & & & \\
\hline Total & 183 & 77.2 & 54 & 22.8 & 237 & 100 & & & \\
\hline
\end{tabular}

${ }^{\star} \mathrm{P}<0.05=$ statistical significance.

Table 3 - Relation between anterior open bite and sucking a pacifier in the three dentitions. Santo Expedito do Sul-RS, 2008.

\begin{tabular}{|c|c|c|c|c|c|c|c|c|c|}
\hline \multirow{3}{*}{ Pacifier sucking } & \multicolumn{6}{|c|}{ Open bite } & \multirow{3}{*}{$\mathbf{p}$} & \multirow{3}{*}{ OR } & \multirow{3}{*}{ Cl 95\% } \\
\hline & \multicolumn{2}{|c|}{ No } & \multicolumn{2}{|c|}{ Yes } & \multicolumn{2}{|c|}{ Total } & & & \\
\hline & $n$ & $\%$ & $\mathbf{n}$ & $\%$ & $\mathbf{n}$ & $\%$ & & & \\
\hline Deciduous & & & & & & & $\star<0.001$ & 2.857 & $1.572-5.192$ \\
\hline Absent & 18 & 100.0 & 0 & 0 & 18 & 100 & & & \\
\hline Present & 7 & 35.0 & 13 & 65.0 & 20 & 100 & & & \\
\hline Total & 25 & 65.8 & 13 & 34.2 & 38 & 100 & & & \\
\hline Mixed & & & & & & & $\star 0.001$ & 1.409 & $1.134-1.750$ \\
\hline Absent & 53 & 88.3 & 7 & 11.7 & 60 & 100 & & & \\
\hline Present & 37 & 62.7 & 22 & 37.3 & 59 & 100 & & & \\
\hline Total & 90 & 75.6 & 29 & 24.4 & 119 & 100 & & & \\
\hline Permanent & & & & & & & $\star 0.010$ & 1.266 & $1.069-1.499$ \\
\hline Absent & 32 & 97.0 & 1 & 3.0 & 33 & 100 & & & \\
\hline Present & 36 & 76.6 & 11 & 23.4 & 47 & 100 & & & \\
\hline Total & 68 & 85.0 & 12 & 15.0 & 80 & 100 & & & \\
\hline
\end{tabular}

${ }^{\star} \mathrm{p}<0.05=$ statistical significance. 
There was a statistical relation to the variable anterior open bite and the frequency of daily use of the pacifier sucking habit in the deciduous and mixed dentitions $(p<0.005)$. The children with deciduous teeth that do not use pacifiers or used only to sleep had $11.5 \%$ of anterior open bite. On the other hand, the students in the deciduous dentition who used a pacifier all the time, such as during the day and night in childhood, had $88.9 \%$ of anterior open bite. In bivariate analysis, children who sucked only to sleep were less likely to have open bite than those that used all the time (OR $=0.02,95 \% \mathrm{CI} 0.00$ to 0.25$)$. In the mixed dentition, those who did not use pacifier or used it only to sleep and had open bite was $11.7 \%$ and those that sucked all the time and had open bite was $47.6 \%$. Children who sucked only to sleep were less likely to have open bite than those that used all the time ( $\mathrm{OR}=0.23,95 \% \mathrm{CI} 0.09$ to 0.56$)$. The children with permanent teeth and open bite who used a pacifier at all times had a percentage of $25 \%$, however, there was no statistically significant association $(\mathrm{p}>0.05)$ (Table 5).

Table 4 - Relation between open bite and duration of pacifier habit on the dentition. Santo Expedito do Sul/RS, 2008.

\begin{tabular}{|c|c|c|c|c|c|c|c|c|c|}
\hline \multirow{3}{*}{ Duration of habit } & \multicolumn{6}{|c|}{ Open bite } & \multirow{3}{*}{$\mathbf{p}$} & \multirow{3}{*}{ OR } & \multirow{3}{*}{ Cl $95 \%$} \\
\hline & \multicolumn{2}{|c|}{ No } & \multicolumn{2}{|c|}{ Yes } & \multicolumn{2}{|c|}{ Total } & & & \\
\hline & $\mathbf{n}$ & $\%$ & $n$ & $\%$ & $n$ & $\%$ & & & \\
\hline Decidious & & & & & & & $\star<0.001$ & 38.333 & $5.525-265.98$ \\
\hline 0 to 2 years & 23 & 88.5 & 3 & 11.5 & 26 & 100 & & & \\
\hline$>2$ to 9 years & 2 & 16.7 & 10 & 83.3 & 12 & 100 & & & \\
\hline Total & 25 & 65.8 & 13 & 34.2 & 38 & 100 & & & \\
\hline Mixed & & & & & & & $\star<0.001$ & 6.869 & $2.732-17.269$ \\
\hline 0 to 2 years & 68 & 88.3 & 9 & 11.7 & 77 & 100 & & & \\
\hline$>2$ to 9 years & 22 & 52.4 & 20 & 47.6 & 42 & 100 & & & \\
\hline Total & 90 & 75.6 & 29 & 24.4 & 119 & 100 & & & \\
\hline Permanent & & & & & & & 0.055 & 3.360 & $0.952-11.853$ \\
\hline 0 to 2 years & 48 & 90.6 & 5 & 9.4 & 53 & 100 & & & \\
\hline$>2$ to 9 years & 20 & 74.1 & 7 & 25.9 & 27 & 100 & & & \\
\hline Total & 68 & 85.0 & 12 & 15.0 & 80 & 100 & & & \\
\hline
\end{tabular}

${ }^{\star} p<0.05=$ statistical significance.

Table 5 - Relation between anterior open bite and the frequency of the pacifier habit in the three dentitions. Santo Expedito do Sul/RS, 2008.

\begin{tabular}{|c|c|c|c|c|c|c|c|c|c|}
\hline \multirow{3}{*}{ Frequency of habit } & \multicolumn{6}{|c|}{ Open bite } & \multirow{3}{*}{$\mathbf{p}$} & \multirow{3}{*}{ OR } & \multirow{3}{*}{ Cl $95 \%$} \\
\hline & \multicolumn{2}{|c|}{ No } & \multicolumn{2}{|c|}{ Yes } & \multicolumn{2}{|c|}{ Total } & & & \\
\hline & $\mathbf{n}$ & $\%$ & $\mathbf{n}$ & $\%$ & $\mathbf{n}$ & $\%$ & & & \\
\hline Deciduous & & & & & & & $<\star 0.001$ & 0.026 & $0.003-0.257$ \\
\hline No or/and only to sleep & 24 & 82.8 & 5 & 17.2 & 29 & 100 & & & \\
\hline All the time & 1 & 11.1 & 8 & 88.9 & 9 & 100 & & & \\
\hline Total & 25 & 65.8 & 13 & 34.2 & 38 & 100 & & & \\
\hline Mixed & & & & & & & $\star 0.001$ & 0.232 & $0.096-0.562$ \\
\hline No or/and only to sleep & 70 & 84.3 & 13 & 15.7 & 83 & 100 & & & \\
\hline All the time & 20 & 55.6 & 16 & 44.4 & 36 & 100 & & & \\
\hline Total & 90 & 75.6 & 29 & 24.4 & 119 & 100 & & & \\
\hline Permanent & & & & & & & 1.00 & 0.360 & $0.103-1.261$ \\
\hline No or/and only to sleep & 50 & 89.3 & 6 & 10.7 & 56 & 100 & & & \\
\hline All the time & 18 & 75.0 & 6 & 25.0 & 24 & 100 & & & \\
\hline Total & 68 & 85.0 & 12 & 15.0 & 80 & 100 & & & \\
\hline
\end{tabular}

${ }^{\star} p<0.05=$ statistical significance. 


\section{DISCUSSION}

The malocclusions are result of changes that occur in the growth of some components, depending on the interaction of variables related to heredity and environment, including the positive and harmful stimuli present mainly in the formation and development of the orofacial complex during childhood and adolescence. However, the range of conditions considered for evaluation of the occlusion characteristics, both for primary, mixed and permanent dentition, gives it very different epidemiological characteristics, making the comparative analysis more difficult. The magnitude of the tendency in prevalence and severity of malocclusion have been difficult to measure, because of the difficulty of calibration of indexes and variety of indicators. Despite the large number of studies, different criteria for registration of occlusal condition, limit the comparisons between the results of different epidemiological surveys. However, in the analysis of occurrence of malocclusion, it can be noticed by several reported studies that the prevalence is high among students and therefore interferes on the quality of life of individuals, it consists of a public health problem. ${ }^{11}$ However, there is great possibility for prevention and treatment when these problems are diagnosed in different locations. ${ }^{12}$

The anterior open bite malocclusion, the dependent variable of this study, represents a major problem in the area of oral health due to its high incidence and character of early onset. This malocclusion is associated with an imbalance in the neuromuscular system with an impact on the structures and functions of the stomatological system. ${ }^{12}$ In this study there was a $34.2 \%$ prevalence of anterior open bite in deciduous teeth, resembling the study by Tomita et $\mathrm{al}^{13}$ and Mendes, Valencia and Lima, ${ }^{14}$ where the frequency of anterior open bite in the deciduous dentition had a percentage of $27.7 \%$ and $29.7 \%$ respectively among students. A higher prevalence occurred in the study by Clemens and Sanchez ${ }^{15}$ in which a percentage of $62.38 \%$ of anterior open bite in this dentition was obtained.

In the study by Thomas and Valencia ${ }^{16}$ the anterior open bite showed a lower percentage, totaling $15.5 \%$ of the analyzed children, contrary to other studies showing that malocclusion is one of the most common changes observed in the primary dentition. At this age the treatment and development of interceptive measures is important, as well as continuing education programs in public health for the prevention of malocclusion. The percentage of anterior open bite found in the permanent dentition in the present study was $15 \%$, a result that resembles the one found in schoolchildren aged 12 to 15 years in Porto Alegre. ${ }^{5}$ Although Lima et al ${ }^{17}$ have reported much lower values in their study, a total percentage of $0.40 \%$ of the children. As in the study by Marques et al ${ }^{18}$ anterior open bite showed a low percentage with $3.3 \%$ of schoolchildren.

In the present study there was an association between pacifier sucking habit and the presence of anterior open bite with a percentage of $36.5 \%$, which can be compared with the mentioned national studies chronologically performed by Forte and Bosco, ${ }^{6}$ Pires, Rocha and Cangussu, ${ }^{19}$ Souza Vasconcello, ${ }^{20}$ Ignacchiti et al, ${ }^{21}$ Tomita et al, ${ }^{13}$ Rochelle, ${ }^{2}$ Maciel and Leite, ${ }^{22}$ Albuquerque $\mathrm{Jr}$ et al, ${ }^{7}$ where the presence of anterior open bite is strongly associated with the habit of sucking a pacifier. Great part of the child population has the non-nutritive habit of sucking a pacifier, which may lead to anterior open bite, although the literature admits that habits during the primary dentition have little or no effect in the long run, on the teeth. But the persistence of the habits in the mixed dentition can cause an anterior open bite. ${ }^{22}$

An important fact found in this study was the progressive decrease in the prevalence of anterior open bite with growth and development of the individual, which is against the results found in others studies ${ }^{15,17,23}$. A tendency toward self-correction of the problem was observed, especially when passing from the deciduous to the mixed dentition. Children who have addictive oral habits with physical and psychological development tend to abandon the habits that favor the occurrence of anterior open bite. Eliminating the cause, functional balance normalizes the situation spontaneously. Hence, the importance of emphasizing the elimination of vicious habits in the early ages.

It is known that the severity and establishment of anterior open bite associated with oral habits depends on the intensity, duration and frequency of 
these habits - called the Graber's triad. Regarding the period in which habits may remain without resulting in general problems for the stomatognathic system, the authors argue that when the sucking habit persisted until 4 years of age, there is a higher prevalence of anterior open bite, as well as the probability of reverting the malocclusion is considered satisfactory when the habit is removed. If the child gives up the habit during the primary dentition, there is the possibility of self-correcting anterior open bite. ${ }^{8}$ Another author states that if the habit persists until around 3 years of age it will cause fewer changes in occlusion, generally affecting only the anterior region of the jaws, and then with the stimulus withdrawn, they follow their normal growth. ${ }^{2}$ In fact, the longer the habit persists, the greater the proportion of children with open bite malocclusion among other malocclusions. ${ }^{5,24}$ In a study in Manaus, AM, the authors concluded that the duration of the pacifier habit was higher among children who had open bite. ${ }^{25}$ These results confirm the findings in this study that the frequency of daily use and duration in years of sucking a pacifier had a strong influence on anterior open bite malocclusion in the deciduous and mixed dentitions.
The prevalence of malocclusion in this study was high, demonstrating how important the recognition of malocclusion is, as an important factor not only regarding the need for treatment, but for educational and preventive activities, which should be part of a development program that contemplate the health of this town. Emphasizing the importance of early elimination of harmful oral habits, and a correct diagnosis by the dentist and / or orthodontist for prevention of malocclusion, especially the anterior open bite.

\section{CONCLUSIONS}

Based on these results it can be concluded that:

- The prevalence of open bite in children from the city of Santo Expedito do Sul was $22.8 \%$.

- The presence of oral habits, like pacifier use, was strongly associated with anterior open bite malocclusion in all three dentitions.

- The frequency and duration of daily use in years of pacifier sucking habits were strongly associated with anterior open bite malocclusion in the deciduous and mixed dentition, however, both variables were not associated with the permanent dentition. 


\section{REFERENCES}

1. Medeiros-Bezerra PKM, Cavalcanti AL, Bezerra PM, Moura C. Maloclusões, tipos de aleitamento e hábitos bucais deletérios em pré-escolares um estudo de associação. Pesq Bras Odontopediatr Clín Int. 2005;5(3):267-74.

2. Rochelle IMF. Amamentação, hábitos deletérios bucais e o equilíbrio funcional da oclusão decídua [dissertação]. Piracicaba (SP): Universidade Estadual de Campinas; 2005

3. Pereira RS. Prevalência das maloclusões nos alunos de 12 anos da escola Odete Barboso do Distrito de Caracará, Sobral, Ceará, 2005, Universidade Estadual Vale do Acaraú [monografia]. Sobral (CE): Universidade Estadual Vale do Acaraú; 2005.

4. Gimenez CMM, Moraes ABA, Bertoz AP, Bertoz FA, Ambrosano GB. Prevalência da más oclusões na primeira infância e sua relação com as formas de aleitamento e hábitos infantis. Rev Dental Press Ortod Ortop Facial. 2008;13(2):70-83.

5. Sousa RLS, Lima RB, Florêncio Filho C, Lima KC, Diógenes AMN. Prevalência e fatores de risco da mordida aberta anterior na dentadura decídua completa em pré-escolares na cidade de Natal/RN. Rev Dental Press Ortod Ortop Facial. 2007;12(2):129-38.

6. Forte FDS, Bosco VL. Prevalência de mordida abeta anterior e sua relação com hábitos de sucção não nutritiva. Pesq Bras Odontopediatr Clín Int. 2001;1(1):3-8.

7. Albuquerque Junior HR, Barros AMM, Braga JPV, Carvalho MF, Maia MCG. Hábito bucal deletério e má-oclusão em pacientes da clínica infantil do curso de Odontologia da Universidade de Fortaleza. Rev Bras Prom Saúde. 2007;20(1):40-5

8. Adair O, Steven M. Non nutritive sucking. In: Annual Session American Academy of Pediatric Dentistry 50th 1997 May; Philadelphia: AAPD; 1997.

9. IBGE. Censo demográfico, 2000 [Acesso 2006 nov. 17]. Disponível em: http://www. ibge.gov.br.

10. Organização Mundial da Saúde. Levantamento Epidemiológico Básico de Saúde Bucal. 4a ed. São Paulo: Ed. Santos; 1999.

11. Alves TDB, Gonçalves APR, Alves AN, Rios FC, Silva LBO. Prevalência de oclusopatia em escolares de 12 anos de idade: estudo realizado em uma escola pública do município de Feira de Santana-BA. RGO: Rev Gaúcha Odontol. 2006;54(3):269-73.

12. Peres KG, Tomita NE. Oclusopatias. In: Antunes JLF, Peres MA. Epidemiologia da saúde bucal. Rio de Janeiro: Guanabara Koogan; 2006. p. 83-101.

13. Tomita LM, Carrascoza KC, Possobori RF, Ambrosano GMB, Moraes ABA. Relação entre tempo de aleitamento materno, introdução de hábitos orais e ocorrência de maloclusões. Rev Facul Odontol Passo Fundo. 2004;9(2):101-4
14. Mendes ACR, Valença AMG, Lima CCM. Associação entre aleitamento, hábitos de sucção não-nutritivos e maloclusões em crianças de 3 a 5 anos. Ciênc Odontol Bras. 2008;11(1):67-75

15. Clemens C, Sanchez MF. Prevalência de mordida aberta anterior em escolares de Porto Alegre. Rev Facul Odontol. 1979-1982(21-24):139-52.

16. Thomas EBAF, Valença AMG. Prevalência de má-oclusão e fatores relacionados à sua ocorrência em pré-escolares da cidade de São Luís-MA- Brasil. Rev Pós Grad. 2005;12(2):212-21.

17. Lima RB, et al. Oclusopatia na dentição decídua: prevalência em pré-escolares da cidade do Natal-RN. Rev Bras Epidemiol. 2004.

18. Marques LS, Barbosa CC, Ramos-Jorge ML, Pordeus IA, Paiva SM. Prevalência de maloclusão e necessidade de tratamento ortodôntico em escolares de 10 a 14 anos de idade em Belo Horizonte, Minas Gerais, Brasil: enfoque psicossocial. Cad Saúde Pub. 2005;21(4):1099-106.

19. Pires DM, Rocha MCS, Cangussu MCT. Prevalência de oclusopatias na dentadura mista em escolares Salvador/BA. Rev Bras Odontol. 2001;58(6):414-17.

20. Souza NB, Vasconcelos TC. A influência de hábitos orais como fator etiológico de mordida aberta anterior. Rev Centro Esp Fonoaudiol Clín. 2003;5:235-40.

21. Ignacchitti PR, et al. Hábitos de sucção de chupeta e mordida aberta anterior na criança com dentição decídua. Rev Centro Esp Fonoaudiol Clín. 2003;5:241-5.

22. Maciel CTV, Leite ICG. Aspectos etiológicos da mordida aberta anterior e suas implicações na funções orofaciais. Pro-Fono Rev Atual Cient. 2005;17(3):293-302.

23. Valente A, Mussolino ZM. Freqüência de sobressaliência, sobremordida e mordida aberta na dentição decídua. Rev Odontol Univ São Paulo. 1989;3(3):402-7.

24. Furtado ANM, Vedovello Filho M. A influência do período de aleitamento materno na instalação dos hábitos de sucção não nutritivos e na ocorrência de maloclusão na dentição decídua. RGO: Rev Gaúcha Odontol. 2007;55(4):335-41.

25. Galvão ACU, Menezes SFL, Nemr K. Correlação de hábitos orais deletérios entre crianças de 4:00 a 6:00 anos de escola pública e escola particular da cidade de Manaus AM. Rev Centro Esp Fonoaudiol Clín. 2006;8(3):328-36. 